\title{
In Vitro Digestibility and Rumen Fermentation of Grass or Rice Straw Basal Diet With or Without Complete Rumen Modifier Supplementation
}

\author{
Yulistiani D, Puastuti W, Widiawati Y \\ Indonesian Research Institute for Animal Production \\ PO Box 221, Bogor 16002, West Java, Indonesia \\ dwiyulistiani@yahoo.com
}

\begin{abstract}
An in vitro study was conducted to evaluate the supplementation of complete rumen modifier (CRM) to elephant grass or rice straw basal diet. CRM is feed additive consisting of a mixture of defaunator, methanogenesis inhibitor and bacterial growth factors. The diet was formulated in iso energetic and iso protein contained CP $16 \%$ and ME $2.3 \mathrm{MJ} / \mathrm{kg}$. The diet was fermented for 48 hours under anaerobic condition at $39{ }^{\circ} \mathrm{C}$. Experiment was conducted in a completely randomized design in $2 \times 2$ factorial arrangement using 2 levels of type of basal diet (Napier grass and rice straw) and 2 levels of CRM supplementation $(0$ and $2 \%)$. The parameters recorded were apparent digestibility of grass substrate, gas production, methane production and bacterial and protozoal counts. Total gas and methane produced during incubation was recorded at 2, 4, 8, 12, 16, 24, 36 and 48 hours. Results from the study show that DM and OM digestibility, bacterial and protozoal population were significantly affected by the interaction between CRM supplementation and type of basal diet. CRM supplementation in rice straw basal diet increased DM and OM by 27\% and $23,48 \%$ respectively, but it did not increase in grass basal diet. Bacterial population was increased by CRM supplementation in grass basal diet, in contrast, in rice straw basal diet, CRM supplementation decreased bacterial population. Whereas protozoal population was decreased both in grass and rice straw basal diet, the decreased was about $63.26 \%$ and $64 \%$ respectively for grass and rice straw basal diet. Methane production tended $(\mathrm{P}<0.07)$ to decrease by $\mathrm{CRM}$ supplementation in rice straw basal diet. From this study, it can be concluded that CRM supplementation was able to improve the fermentability of rice straw basal diet and tended to decrease proportion of methane production. CRM supplementation did not have any effect on grass basal diet.
\end{abstract}

Key Words: Rumen Modifier, Methane, Rumen Fermentation, Supplementation

\section{INTRODUCTION}

Lack of continual feed availability either in quantity or quality throughout the year causes low productivity of ruminants in Indonesia particularly in dry season, in which the availability of forage is limited. One of reasons of limited forage availability is the priority land use is for food crop planting, and this condition gets worse by the conversion of grazing area into housing and factory. In this condition, utilization of crop by products is one of very suitable alternatives for ruminants feed because this feed is not compete with human food and abundantly available. Rice straw is abundantly available in rice based farm system, in Indonesia in 2014 rice harvest areas was about 13,793,640 ha (BPS 2015) in which each ha of harvest will produce straw 5-8 ton/ha, traditionally rice straw used as feed for large ruminants, among other usages. However, fermentation of low quality forage such as crop by-products in the rumen will result in higher methane production. Methane emission by ruminants have negative effects to the animal and causes green house effect to environment. Methane which is the end products from feed fermentation, is formed through methanogenesis process (Fonty \& Morvan 1995). Methanogenesis can cause loss of energy up to $15 \%$ of the digested energy. Beside that, methane from rumen contributes $15-25 \%$ of the total global green house gas in the world (Stewart 1999). Therefore, 
reducing methane emission in ruminants will increase feed efficiency and have potential long-term environment benefit. Possible intervention of reducing emission include the use of better quality feed and feed balancing to lower enteric methane emission (FAO 2013) as a result of improved efficiency of rumen fermentation (Patra 2012). Various feed additives were reported to be effective to lower enteric methanogenesis; one of them is CRM which was formulated in the Indonesian Research Institute for Animal Production and was reported able to reduce methane production in sheep fed on high fibrous forages (Thalib et al. 2010). CRM is a mixture of feed additive, consist of many components with multi function such as defaunator, methanogenesis inhibitor, bacterial growth factor and fiber digestion stimulaton and $\mathrm{CO}_{2}$ anti reductance. The main component of CRM was Sapindus rarak in the form of finely ground fruit. Saponin in Sapindus rarak was effective as defaunator and methanogenesis inhibitor. Other componens of CRM was leguminous leaves from sesbania and albizia, and minerals such as $\mathrm{Zn}$ and $\mathrm{Cu}$ which able to increase the growth of fibrolytic bacteria increased its ability to digest cellulolytic substrate (Thalib 2012). Previously, CRM was evaluated in reducing methane production in vitro using a single substrate (Thalib 2004). It is hypothesized that in a complete diet with balancing all nutrients inspite of forage type in the diet, the diet will have similar feed efficiency and methane production. Therefore this research was conducted with objective to evaluate CRM supplementation in ration with different basal diet (rice straw or Napier grass) on in vitro methane production and digestibility.

\section{MATERIAL AND METHODS}

An in vitro study was conducted to evaluate four diet treatments. All diets were formulated to contain iso energetic and iso protein to meet the requirement of the growth of male lambs. Protein content of the diet was $16 \%$, with ME content $2.3 \mathrm{MJ} / \mathrm{kg}$. Two different basal diets namely elephant grass or rice straw were used in the experiment with or without CRM supplementation. CRM was supplemented at $2 \%$ of feed DM which was the optimum level of CRM supplementation in reducing methane emission in vitro (Yulistiani et al. 2012). The composition of the diet presented in Table 1. The diet treatment as follow:

R1: Napier Grass basal diet

R2: Napier Grass basal diet + CRM

R3: Rice straw basal diet

R4: Rice straw basal diet + CRM

The fermentation was conducted for 48 hours under anaerobic condition at $39^{\circ} \mathrm{C}$. Medium for incubation was prepared according to Menke \& Steingass (1988). The parameters recorded were apparent digestibility, $\mathrm{NH}_{3}-\mathrm{N}$, gas production, methane production and bacterial and protozoal count. The gas production was recorded at 2, 4, 6, $8,10,24$, and $48 \mathrm{~h}$ incubation at $39^{\circ} \mathrm{C}$. The calculation of the kinetics based on exponential equation $\mathrm{P}=\mathrm{A}+\mathrm{B}\left(1-\mathrm{e}^{-\mathrm{ct}}\right)$ from Orskov and McDonald (1979), where $\mathrm{P}$ is the gas production at time $\mathrm{t}, \mathrm{A}$ is the production from fermentation of soluble fraction, $\mathrm{B}$ is the gas production from fermentation of insoluble fraction, $\mathrm{c}$ is the rate of gas production from $\mathrm{B}$ fraction, $\mathrm{A}+\mathrm{B}$ is the potential of gas production and $\mathrm{t}$ is the incubation time. Gas $\mathrm{CH}_{4}$ produced from fermentation was analysed according to procedure of Tjandraatmadja (1981). 
Table 1. Ration composition of diet treatments

\begin{tabular}{lcc}
\hline \hline Ingredients $(\%)$ & Grass basal diet & Rice straw basal diet \\
\hline Elephant grass & 40.00 & - \\
Rice straw & - & 30.00 \\
Rice barn & 10.00 & 10.00 \\
Coconut meal & 10.00 & 10.00 \\
Pollard & 9.90 & 19.54 \\
Maize grain & 15.00 & 9.80 \\
Soy bean meal & 7.00 & 10.00 \\
Molasses & 5.00 & 7.00 \\
Urea & 1.00 & 1.00 \\
ZA & 0.41 & 0.21 \\
Salt & 0.37 & 0.35 \\
DCP & - & 1.13 \\
CaCO & & - \\
Calculated Nutrient content $(\%):$ & 1.30 & \\
$\mathrm{CP}$ & & 16.00 \\
$\mathrm{ME}(\mathrm{MJ} / \mathrm{kg})$ & 15.60 & 2.31 \\
$\mathrm{NDF}$ & 2.27 & 39,53 \\
$\mathrm{ADF}$ & 42.05 & 25.41 \\
$\mathrm{Ca}$ & 24.65 & 0.80 \\
$\mathrm{P}$ & 0.80 & 0.54 \\
\hline
\end{tabular}

Total gas produced was collected and measured using volumetric syringes, with $\mathrm{T}$ system connector, gas was injected into two tubes which is containing sodium hydroxide 6 $\mathrm{N}$ and were connected in serial model, then the gas release was collected in measuring syringes and was considered as $\mathrm{CH}_{4}$. At the end of the incubation period, the $\mathrm{pH}$ in fermented fluid was measured, while the fermented fluid was collected for the estimation of ammonia nitrogen, dry matter digestibility, bacterial and protozoal count. In vitro dry matter digestibility (IVDMD) of substrate was determined by vacuum filtration through a pre-weighed sintered crucible. The crucible containing feed residues were dried in an oven at $100^{\circ} \mathrm{C}$ for 24 hours to determine DM. Bacterial population was determined using roll tube method according to procedure of Ogimoto \& Imai (1981) and protozoal count was measured using haemocytometer. The experiment was conducted in a completely randomized design in $2 \times 2$ factorial arrangement using 2 levels of type of basal diet (Napier grass and rice straw) and 2 levels of CRM supplementation (0 and 2\%). Data obtained were analysed using analysis of variance from SAS program (SAS 9v1, SAS 2002). Means were compared using Duncan's Multiple Range Test.

\section{RESULTS AND DISCUSSION}

Gas production kinetics shown in Table 1. No interaction between basal diet and CRM supplementation on gas produced from soluble fraction, insoluble fraction or rate of gas production or potential gas production. All these variables were affected by type of basal 
diet. All of these parameters were higher in grass basal diet, except for gas produced from soluble fraction. The higher gas production and the rate of gas production in grass basal diet indicate that this diet had higher fermentability though the diet was formulated in iso energy and iso nitrogen (Table 1), but the degradability of this basal diet affected the total of feed fermentability. Forages varied significantly in their NDF content and NDF digestibility. Grasses though have higher NDF content, their NDF were generally more digestible than legumes (FAO 2013). In this study, grass used to formulate diet was cut at 45 days from previous harvest, so it can be expected that digestibility was higher than rice straw which was harvested at mature stage. The higher fermentability of grass basal diet is also reflected in figure 1, in which the cumulative gas production of grass basal diet after 12 hours incubation was higher than rice straw basal diet.

Table 2. Kinetics of gas production of experimental diet during $48 \mathrm{~h}$ incubation

\begin{tabular}{lccccc}
\hline \hline \multirow{2}{*}{ Basal diet } & \multirow{2}{*}{ CRM $(\%)$} & \multicolumn{5}{c}{ Variables } \\
\cline { 3 - 6 } & 0 & $\mathrm{~A}(\mathrm{ml})$ & $\mathrm{B}(\mathrm{ml})$ & $\mathrm{c}(\mathrm{ml} / \mathrm{h})$ & $\mathrm{A}+\mathrm{B}(\mathrm{ml})$ \\
\hline Grass & 1.21 & 117.32 & 0.10 & 118.68 \\
& 2 & 1.36 & 119.20 & 0.10 & 120.41 \\
Rice straw & 0 & 2.17 & 98.34 & 0.09 & 100.51 \\
& 2 & 2.35 & 100.95 & 0.08 & 103.30 \\
\hline Basal diet & $*$ & $* *$ & $*$ & $* *$ \\
CRM & & $\mathrm{NS}$ & $\mathrm{NS}$ & $\mathrm{NS}$ & $\mathrm{NS}$ \\
Interaction basal diet $\times \mathrm{CRM}$ & $\mathrm{NS}$ & $\mathrm{NS}$ & $\mathrm{NS}$ & $\mathrm{NS}$ \\
\hline
\end{tabular}

NS: non significant, $* \mathrm{P}<0.05 ; * * \mathrm{P}<0.001$

A: considered as gas produced from the fermentation of immediately soluble materials

B: gas produced from the fermentation insoluble fraction, but fermentable

$\mathrm{C}$ : the rate of gas production of $\mathrm{B}$ fraction

$\mathrm{A}+\mathrm{B}$ : extent of gas production

CRM supplementation did not affect gas production. Similarly there was no interaction between type of basal diet and CRM supplementation on total methane production (Table 3). However, when the methane production was calculated as the proportion from total gas, there was tended $(\mathrm{P}<0.078)$ significant interaction between type of basal diet and CRM supplementation.

The reduction of methane proportion in rice straw basal diet was 13.38\%. Gas production is related to degradation of feed as a result from fermentation of feed by microbial inoculum. Gas production is an indicator of the ability of inoculum to digest feed. In this study, digestibility and gas production of grass basal diet were not affected by CRM supplementation; this indicates that CRM did not have negative effect on feed fermentation. The higher gas production in grass basal diet was also followed by the high IVOMD of this diet (Table 4). Previously reported by Yulistiani et al. (2012) that sheep fed on corn cob silage adapted to CRM supplementation, when their rumen fluid was used as inoculum in grass substrate incubation was able to reduce methane production but did not affect IVOMD. 


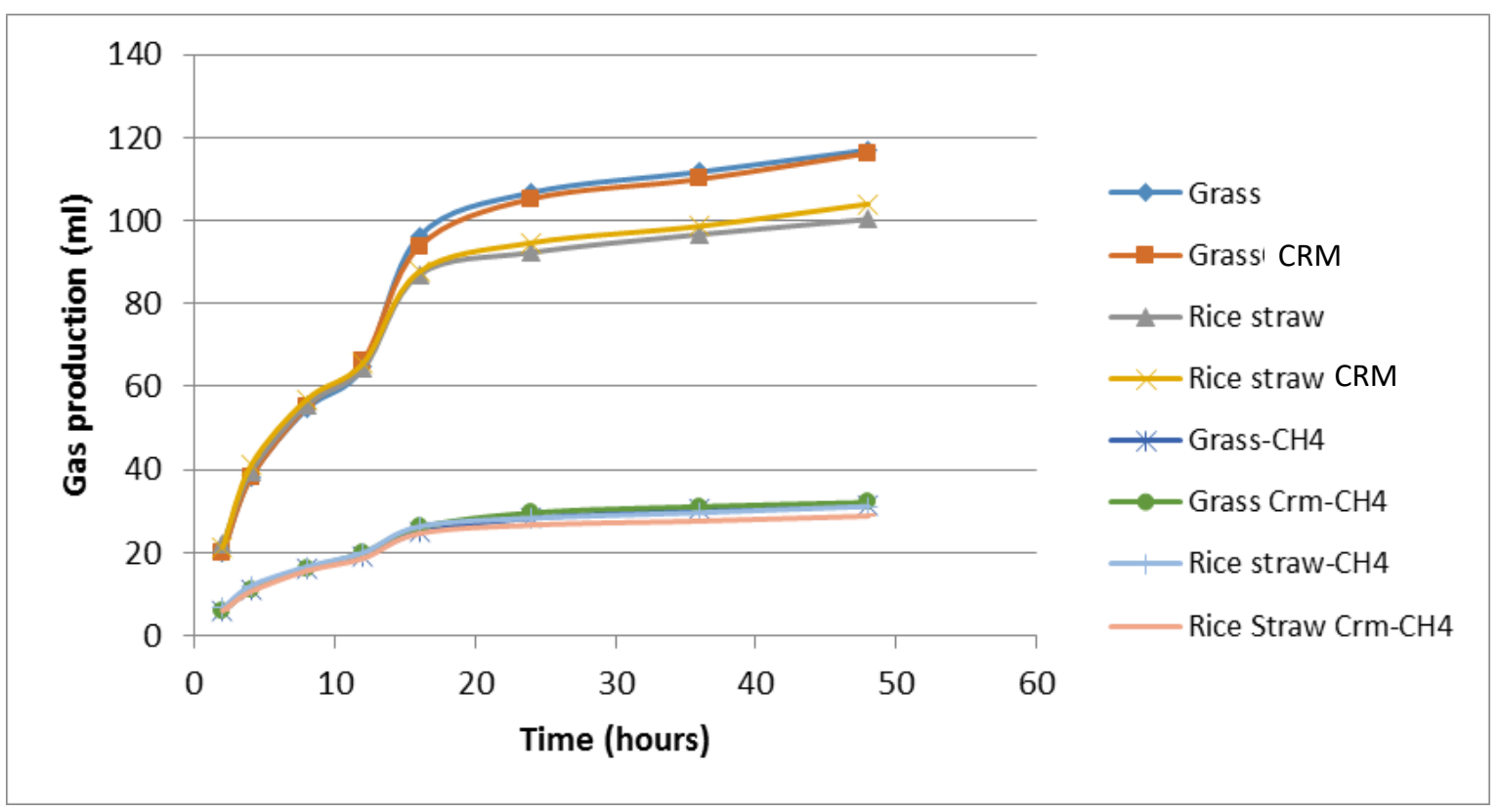

Figure 1. Cumulative total gas production and methane production of experimental diet during 48 hours incubation

The interaction between CRM supplementation and type of basal diet was significantly different on DM and OM digestibility. CRM supplementation in grass basal diet did not increase DM or OM digestibility, but in rice straw basal diet CRM supplementation increased DM and OM digestibility by 20\%. This indicates that CRM supplementation have more effect on low quality basal diet than in higher quality. This could be due to mineral $\mathrm{Zn}$ and $\mathrm{Cu}$ in $\mathrm{CRM}$ which function as stimulator microbial growth, hence was able to stimulate microbial synthesis and increase feed digestibility rice straw basal diet. Thalib et al. (2010) reported that CRM supplementation increased rumen fermentation by the increase digestibility of ration by sheep fed on femented rice straw supplemented by CRM. On the other hand, Bharathidhasan et al. (2013) reported no significant effect of DM digestibility of napier grass diet supplemented by purified saponin.

Table 3. Total gas, methane production and proportion of methane to total gas during 48 hours incubation

\begin{tabular}{lcccc}
\hline \hline & & \multicolumn{3}{c}{ Variables } \\
\cline { 3 - 5 } Basal diet & CRM (\%) & $\begin{array}{c}\text { Total gas at 48h } \\
\text { incubation (ml) }\end{array}$ & $\begin{array}{c}\text { Methane } \\
\text { production at 48h } \\
\text { incubation (ml) }\end{array}$ & $\begin{array}{c}\% \text { methane/total } \\
\text { gas }\end{array}$ \\
\hline Grass & 0 & 117.25 & 31.37 & 26.76 \\
Rice straw & 2 & 116.25 & 32.12 & 27.63 \\
& 0 & 101.00 & 31.17 & 30.86 \\
\hline Basal diet & 2 & 104.00 & 27.83 & 26.76 \\
CRM & & $* *$ & NS & NS \\
Interaction basal diet $\times$ CRM & NS & NS & NS \\
\hline
\end{tabular}

NS: non significant, $* \mathrm{P}<0.05 ; * * \mathrm{P}<0.001$ 
Table 4.In vitro dry matter (IVDMD) and organic matter digestibility (IVOMD) of the experimental diet after 48 hours incubation

\begin{tabular}{lccc}
\hline \hline \multirow{2}{*}{ Basal diet } & \multirow{2}{*}{ CRM } & \multicolumn{2}{c}{ Parameter } \\
\cline { 3 - 4 } & & IVDMD (\%) & IVOMD (\%) \\
\hline Grass & 0 & 63.28 & 62.41 \\
& 2 & 63.90 & 62.50 \\
Rice straw & 0 & 46.56 & 50.33 \\
& 2 & 59.12 & 62.16 \\
\hline Basal diet & & $* *$ & $* *$ \\
CRM & & $* *$ & $* *$ \\
Interaction basal diet $\times$ CRM & & $* *$ & $* *$ \\
\hline
\end{tabular}

NS: non significant, $* \mathrm{P}<0.05 ; * * \mathrm{P}<0.001$

Bacterial and protozoal population were significantly affected by the interaction between type of diet and CRM supplementation. CRM supplementation in grass basal diet increased total bacterial population, whereas in rice straw basal diet CRM supplementation reduced bacterial population. Protozoal population decreased by CRM supplementation either in grass basal diet or rice straw basal diet. The decrease of protozoal population in both basal diet due to CRM supplementation was about 63\%. CRM with main component of Sapindus rarak has the role asdefaunator (Thalib et al. 2010). Sapindus rarak contained saponin, which was reported to be effective as defaunator and as methanogenesis inhibitor (Thalib 2004), therefore when CRM supplemented to the diet, protozoal population and percentage of methane in rice straw basal diet were decreased. The decrease of protozoal population was also followed by the increased microbial population in grass basal diet, but not in rice straw basal diet. Thalib (2004) previously reported that supplementation of saponin extracted from Sapindus rarak in grass substrate diet was able to reduce protozoa and increased bacterial population, however when Sapindus rarak powder was supplemented, it was able to reduce protozoal population but was not able to increase bacterial population. Sapindus rarak extract contained higher saponin level than that in the Sapindus rarak fruit powder and this may be the reason of different effect between these two different forms.

Eventhough protozoa population decreased significantly (Table 5), but methane production was not decreased significantly by CRM supplementation (Table 3). Similar results on saponin effect was also reported by Ngamsaeng et al. (2006) on cattle fed on rice straw supplemented by mangosteen peel. Patra (2012) stated that defaunation is a method of reducing methane emission due to many methanogens attached on the surface of rumen ciliate protozoa and as endosymbions within the ciliates, which are responsible for up to $37 \%$ of rumen methanogenesis. The decline in methanogenesis as a result from prozotoal removal is strong on high concentrate diet because protozoa produced hydrogen as source for methanogenesis on starch diet (Ezeji et al. 2012). In this study the component of concentrate in rice straw basal diet was higher than grass basal diet (70 and 60\% respectively, Table 1), the decrease of protozoa population did not significantly reduce methane emission. According to Wina et al. (2005) beside methanogens live associated with protozoa which would decrease with decreasing protozoa population, there are also methanogens that reside freely in the rumen might not be affected by saponin addition and still producing methane. 
Table 5. Ruminal $\mathrm{pH}$, concentration of $\mathrm{NH}_{3} \mathrm{~N}$, bacterial and protozoal population of experimental diet during $48 \mathrm{~h}$ incubation

\begin{tabular}{|c|c|c|c|c|c|}
\hline \multirow[b]{2}{*}{ Basal diet } & \multirow[b]{2}{*}{ CRM (\%) } & \multicolumn{4}{|c|}{ Parameter } \\
\hline & & $\mathrm{pH}$ & $\begin{array}{l}\mathrm{NH}_{3} \mathrm{~N} \\
(\mathrm{mg} / \mathrm{dl})\end{array}$ & $\begin{array}{c}\text { Total bacteria } \\
\left(\times 10^{9} \text { colony } / \mathrm{ml}\right)\end{array}$ & $\begin{array}{c}\text { Protozoa }\left(\times 10^{5}\right. \\
\text { cell } / \mathrm{ml})\end{array}$ \\
\hline \multirow[t]{2}{*}{ Grass } & 0 & 6.80 & 36.60 & $9.57^{\mathrm{d}}$ & $5.68^{\mathrm{b}}$ \\
\hline & 2 & 6.82 & 37.06 & $9.85^{\mathrm{b}}$ & $5.23^{\mathrm{d}}$ \\
\hline \multirow[t]{2}{*}{ Rice straw } & 0 & 6.71 & 38.76 & $9.97^{\mathrm{a}}$ & $5.96^{\mathrm{a}}$ \\
\hline & 2 & 6.90 & 42.09 & $9.75^{\mathrm{c}}$ & $5.51^{\mathrm{c}}$ \\
\hline Basal diet & & & $*$ & $* *$ & $* *$ \\
\hline \multicolumn{3}{|l|}{ CRM } & NS & $*$ & $* *$ \\
\hline \multicolumn{3}{|c|}{ Interaction basal diet $\times \mathrm{CRM}$} & NS & $* *$ & $* *$ \\
\hline
\end{tabular}

Different letter in the same column indicates significantly different $(\mathrm{P}<0,05)$

Ruminal $\mathrm{pH}$ in this study was in the range of 6.7-6.9 in normal ranges for fiber and protein digestion (Firkin 1996). $\mathrm{NH}_{3}-\mathrm{N}$ was not affected by CRM supplementation but affected by type of diet. The higher of ruminal $\mathrm{NH}_{3}-\mathrm{N}$ in rice straw basal diet could be due to the higher concentrate content of this diet to achieve iso energy and iso protein diet (Table 1). The $\mathrm{CP}$ content of the component in this concentrate is highly soluble in the rumen buffer medium. No effect of saponin supplementation on methane production was also reported by Manasri et al. (2012) and Norrapoke et al. (2014) in saponin supplementation from mangosteen, and reported by Bharathidhasan et al. (2013) on in purified saponin supplementation, and Mao et al. (2010) in sheep diet supplemented by tea saponin. Although most studies indicated a reduction in ruminal protozoal by saponin supplementation, however, overall effects on ruminal fermentation were not consistent among studies. This variable effect of saponin markedly was due to different diets and feeding.

\section{CONCLUSION}

From this study, it can be concluded that CRM supplementation was able to improve the fermentability of rice straw basal diet and tended to decrease proportion of methane to total gas. The higher fermentability of grass basal diet resulted in no effect of CRM supplementation in this diet.

\section{REFERENCES}

Bharathidhasan A, Viswanathan K, Balakrishnan V, Valli C, Ramesh S, Senthilkumar SMA. 2013. Effects of purified saponin on rumen methanogenesis and rumen fermentation characteristics studied using in vitro gas production technique. Inter J Vet Sci. 2:44-49. www.ijvets.com.

BPS. 2015. Statistik Indonesia 2015. Jakarta (Indonesia): Badan Pusat Stastistik.

FAO. 2013. Mitigation of greenhouse gas emissions in livestock production. In: Gerber PJ, Henderson B, Makkar HPS, editors. Animal Production and Health. Rome (Italy): FAO.

Firkin JL. 1996. Maximizing microbial protein synthesis in the rumen. J Nutr. 126:1347-1354.

Fonty G, Morvan B. 1995. Ruminal methanogenesis and its alternatives. Satellite Symposium of IVth International Symposium on the Nutrition of Herbivores. Clermont-Ferrand, France, September 16-17, 1995. Clermont-Ferrand (France): INRA. p. 34-40. 
Manasri N, Wanapat M, Navanukraw. C. 2012. Improving rumen fermentation and feed digestibility in cattle by mangosteen peel and garlic pellet supplementation. Livest Sci. 148:291-295.

Mao HL, Wang JK, Zhou YY, Liu JX. 2010. Effects of addition of tea saponins and soybean oil on methane production, fermentation and microbial population in the rumen of growing lambs. Livest Sci. 129:56-62.

Menke KH, Steingass H. 1988. Estimation of the energetic feed value obtained from chemical analysis and in vitro gas production using rumen fluid. Anim Res Dev. 28:7-55.

Ngamsaeng A, Wanapat M, Khampa S. 2006. Effects of Mangosteen peel (Garcinia mangostana) supplementation onrumen ecology, microbial protein synthesis, digestibility andvoluntary feed intake in cattle. Pak J Nutr. 5:445-52.

Norrapoke T, Wanapat M, Foiklang S. 2014. Influence of tropical plant sources containing plant secondary compound on rumen fermentation using in vitro gas fermentation technique. Indian J Anim Sci. 84:1004-1010.

Ogimoto K, Imai S. 1981. Atlas of Rumen Microbiology. Tokyo (Japan): Japan Scientific Societies Press.

Orskov ER, McDonald I. 1979. The estimation ofprotein degradability in the rumen from incubationmeasurements weighted according rate of passage. J Agric Sci. 92:499-503.

Kumar PA. 2012. Enteric methane mitigation technologies for ruminantlivestock: a synthesis of current research and future directions. Environ Monit Assess. 184:1929-1952.

SAS. 2002. SAS/STAT User's Guide (Release 9). Carry (USA): SAS Inst, Inc.

Sejian V, Shekhawat I, Ujor V, Ezeji T, Lakritz J, Lal R. 2012. Global climate change: enteric methane reduction strategies in livestock. In: Sejian V, et al., eds. Environmental Stress and Amelioration in Livestock Production. Heidelberg (Germany): Springer-Verlag Berlin. Available from: Veerasamy Sejian.http://www.researchgate.com/. Retrieved on: 08 October 2015.

Stewart CS. 1999. Microbial interaction in the rumen and their potential impact on the survival of Escherichia coli 0157. In: Bell CR, Brylinsky M, Johnson-Green P, editors. The Rumen Microbial Ecosystem. Proceedings of the 8th International Symposium on Microbial Ecology. Ilalifax (Canada): Atlantic Canada Society for Microbial Ecology.

Thalib A. 2004. UJi efektivitas saponin buah lerak Sapindus rarak sebagai inhibitor metanogenesis secara in vitro pada system pencernaan rumen. JITV. 9:164-171.

Thalib A, Widyawati Y, Haryanto B. 2010. Penggunaan Complete Rumen Modifier (CRM) pada ternak domba yang diberi hijauan pakan berserat tinggi. JITV 15:97-104.

Thalib A. 2012. Strategi mitigasi metana enterik dalam meningkatkan produktivitas ternak ruminansia. Dalam: Tiesnamurti B, Nurhayati, Herawati T, Widiawati Y, penyunting. Potensi bahan pakan lokal untuk menurunkan gas metana ternak ruminansia. IAARD Press. p. 262-290.

Tjandraatmadja M. 1981. Anaerobic digestion of fibrous materials. [Thesis]. Agricultural Science, University of Melbourne. Melbourne (Australia): University of Melbourne.

Wina E, Muetzel S, Hoffmann E, Makkar HPS, Becker K. 2005. Saponins containing methanol extract of Sapindus rarak affect microbial fermentation, microbial activity and microbial community structure in vitro. Anim Feed Sci Technol. 121:159-174.

Yulistiani D, Thalib A, Haryanto B, Puastuti W. 2012. The total gas and methane productions of grass incubated in vitro using rumen liquor from sheep adapted to complete rumen modifier supplement. In: Koonawootrittriron K, Suwanasapee T, Jaichansukkit T, Jattawa D, Boonyanuwat K, Skunmun P, editors. Proceedings of the 15th AAAP Animal Science Congress 26-30 November 2012, Thammasat University, Rangsit Campus, Thailand. Bangkok (Thailand): AHAT. p. 3070-3073. 